2. Макух О.С. Довіра як атрибут громадянського суспільства: комунікативний аспект. Вісник НТУУ» КПІ» Політологія. Соиіологія. Право, 2014. - С. 85-89.

3. Концепція розвитку системи надання адміністративних послуг органами виконавчої влади - https://www.kmu.gov.ua/npas/29277890

DOI https://doi.org/10.30525/978-9934-588-92-1-54

\title{
ПСИХОЛОГІЧНЕ НАСИЛЬСТВО ЯК ОДНА 3 ФОРМ БУЛІНГУ УЧАСНИКІВ ОСВІТНЬОГО ПРОЦЕСУ
}

\author{
Градова Ю. В. \\ кандидат юридичних наук, доиент, \\ дочент кафедри конституційного і муніципального права \\ Харківського національного університету імені В. Н. Каразіна \\ м. Харків, Україна
}

Насильство в закладах освіти має різну природу i характер, проявляється як у формі одноразових насильницьких дій, так i у вигляді постійних знущань, принижень і систематичного цькування (булінг), яке становить особливу небезпеку. Булінг (від англ. bully хуліган, задирака, грубіян, "to bully" - задиратися, знущатися) тривалий процес свідомого жорстокого ставлення, агресивної поведінки, щоб заподіяти шкоду, викликати страх, тривогу або ж створити негативне середовище для людини [2].

Кожен здобувач освіти має право на захист під час освітнього процесу від приниження честі та гідності, будь-яких форм насильства та експлуатації, булінгу (цькування), дискримінації за будь-якою ознакою, пропаганди та агітації, що завдають шкоди здоров'ю [1]. Згідно Закону України «Про освіту» здійснення булінгу учасників освітнього процесу $є$ можливим у формі психологічного, фізичного, економічного, сексуального насильства, у тому числі із застосуванням засобів електронних комунікацій (кібербулінг) [3]. У науці розрізняють прямий та непрямий булінг. Прямий булінг має місце, коли стосовно жертви вчиняються такі дії як: штовхання, ляпаси, удари, щипання, кусання; а непрямий булінг передбачає бойкотування, ігнорування, принижуючі жести та погляди тощо. Прямий булінг є більш поширеним в молодших класах, а непрямий - в середніх [4, с. 467]. 
Найчастіше цькування проявляються у формі психологічного насильства, яке може включати: словесні образи, погрози, у тому числі щодо третіх осіб, приниження, переслідування, залякування, інші діяння, спрямовані на обмеження волевиявлення особи [1]. В ході проведеного анонімного анкетування серед учнів 4-9 класів м. Харкова та студентів юридичного факультету Харківського національного університету імені В.Н. Каразіна нам вдалось з'ясувати, що в 33,33\% жертви булінгу стикались $з$ образами і глузуванням в їхню адресу, щодо 18,95\% використовувались прізвиська, а 9,15\% відчували на собі ігнорування та бойкотування. Все це $\epsilon$ проявом психологічного булінгу щодо учасників освітнього процесу, при цьому жертвами і кривдниками за цієї форми виступають як учні, так і вчителі. На жаль, все частіше в матеріалах судових справ фігурують вчителі, які користуючись своїм службовим становищем, вчиняють неправомірні дії щодо учнів, як-то: приниження, перекручування прізвища та видумування образливих прізвиськ (справа № 724/315/20), образи, приниження та ігнорування (справа № 369/4967/19), висловлювання образливих чуток, маніпуляції, словесне чіпляння (справа № 279/2947/19) приниження, погрози, глузування (справа № 639/1214/20).

Вчинення психологічного булінгу є характерним для більш дорослого колективу, коли приходить розуміння, що за фізичне насильство може наступити відповідальність. В Українському інституті дослідження екстремізму вважають, що як раз в старшому віці розповсюдженим стає психологічне насильство [2]. Фізичне насильство найбільш помітне, однак становить менше третини випадків булінгу, в той час як $70 \%$ знущань відбувається словесно. Психологічний булінг на відміну від фізичного, економічного складніше зафіксувати, він не залишає таких «слідів»«: як синці, побої, зіпсовані речі або одяг. Проте наслідки психологічного булінгу бувають набагато тяжчі для жертви i відкладають свій відбиток на тривалий строк. Особи, які піддаються постійним цькуванням у формі образ, глузувань, наклепів, ігнорувань, схильні замикатись в собі та намагатись справитись 3 ситуацією власноруч. В подальшому це дає свій відбиток на поведінці жертви, що може проявлятись у вигляді: уповільнення мислення, зниженої здатності до навчання; відлюдкуватості, уникнення спілкування; ізоляції; заниженої самооцінки, наявності почуття провини; появи швидкої втомлюваності, зниженої спроможності до концентрації уваги; демонстрації страху перед появою інших учасників освітнього процесу; схильності до пропуску навчальних занять; відмови відвідувати заклад освіти 3 посиланням на погане самопочуття; депресивного стану; аутоагресії (самоушкодження); суїцидальних проявів [1]. Багато 
досліджень показують, що жертви булінгу, так само як і агресори мають суттєві проблеми з психічним здоров'ям. Якщо вчасно не помітити зміну поведінки дитини та не надати ій психологічну допомогу - наслідки можуть бути незворотними. Одним із добре відомих факторів ризику самогубства у підлітковому віці $є$ участь у цькування. С. Хинджа та Д. Патчін приходять до висновку, що молодь, яка зазнала традиційних знущань чи кібербулінгу (незалежно це булер чи жертва), отримали вищий бал за шкалою суїцидальних ідей, ніж ті, хто не зазнавав цих форм агресія [5, с. 214]. Китайські дослідники прийшли до висновку, що не тільки агресори та жертви зазнають стрес через булінг, але й свідки також. Тому для зменшення високого рівня самогубств серед підлітків у Китаї потрібно робити ставки на такий важливий захисний фактор як менш негативний стиль подолання цькування («more negative coping styles») [6, с. 277]. Тобто учасникам булінгу слід намагатись подолати стрес від цькування, не пропускаючи весь негатив через себе і не накопичуючи його в собі, оскільки це сприяє психологічним травмам. I в цьому їм мають допомогти як батьки, так і психологи.

Найчастіше булінгу діти піддаються у школі. Проблема полягає у тому, що саме в школі діти проводять більшу частину свого часу, вони знаходяться в одних стінах 3 агресором і не можуть за бажанням залишити клас, школу стикаючись 3 цькуванням. На вулиці це зробити простіше - дитина змінює місце своїх прогулянок, щоб уникати агресорів, в Інтернеті кривдника можна просто заблокувати. Школа місце, де діти знаходять друзів, отримують знання, формують свою особистість, проте подекуди вона перетворюється для дітей у місце, де вони постійно знаходяться під тиском, де їх цькують, ображають, б'ють. За такої ситуації учасникам освітнього процесу потрібно повідомляти про випадки булінгу керівника закладу освіти, який, в свою чергу, має повідомити органи поліції, батьків особи, яка є стороною цькування, службу у справах дітей, центр соціальних служб для сім'ї, дітей та молоді; скликати засідання комісії з розгляду випадку булінгу.

За даними UNICEF 48 \% постраждалих ніколи не розповідали про випадки насильства в закладі освіти, а $25 \%$ - говорили про це не 3 дорослими, а з другом, братом чи сестрою. У випадках булінгу обов'язково потрібно звертатись по допомогу і краще до дорослих, розраховувати тільки на свої сили або чекати, коли кривдники забудуть про свою жертву, не слід.

\section{Література:}

1. Деякі питання реагування на випадки булінгу (цькування) та застосування заходів виховного впливу в закладах освіти: Наказ 224 
Міністерства освіти і науки України № 1646 від 28.12.2019 p. URL: https://zakon.rada.gov.ua/laws/show/z0111-20\#Text (дата звернення 12.10.2020).

2. Методичні рекомендації щодо запобігання та протидії насильству: Додаток до листа Міністерства освіти і науки України № 1/11-5480 18.05.2018 p. URL: https://zakon.rada.gov.ua/rada/show/ v5480729-18 (дата звернення 12.10.2020).

3. Про освіту: Закону України № 2145-VIII 5.09.2017 p. URL: https://zakon.rada.gov.ua/laws/show/2145-19\#Text (дата звернення 12.10.2020).

4. Farmer Th. W., Xie H. Aggression and school social dynamics: The good, the bad, and the ordinary. Journal of School Psychology. 2007. Vol. 45(5). P. 461-478. URL: https://www.sciencedirect.com/journal/ journal-of-school-psychology/vol/45/issue/5 (дата звернення 12.10.2020).

5. S.Hinduja , J. W. Patchin (2010) Bullying, Cyberbullying, and Suicide. Archives of Suicide Research, 14:3. P. 206-221.

6. Suqian Duan, Zhizhou Duan, Ronghua Li, Amanda Wilson, Yuanyuan Wang, Qiufang Jia, Yong Yang, Mengqing Xia, Guosheng Wang, Tingting Jin, Shuilan Wang, Runsen Chen. Bullying victimization, bullying witnessing, bullying perpetration and suicide risk among adolescents: A serial mediation analysis. Journal of Affective Disorders. 2020. Volume 273. P. 274-279.

DOI https://doi.org/10.30525/978-9934-588-92-1-55

\section{ЗАБЕЗПЕЧЕННЯ РЕАЛІЗАЦЇ̈ ПРАВА СПОЖИВАЧІВ НА ДОСТУП ДО ПУБЛІЧНОЇ ІНФОРМАЩІї НА РИНКУ ТЕЛЕКОМУНІКАЦИЙНИХ ПОСЛУГ}

\section{Заярний О. А.}

доктор юридичних наук, дочент, дочент кафедри інтелектуальної власності та інформаційного права Інституту права

Київського національного університету імені Тараса Шевченка м. Київ, Украӥна

Конституційне проголошення у положеннях ч. 2 ст. 34 права кожної людини вільно збирати, зберігати, використовувати i поширювати інформацію усно, письмово або в інший спосіб - на свій вибір [1] 